解説

\title{
生体分子のエレクトロスプレー
}

\author{
山下 雅 道*
}

（受理2003年 8 月26日，掲載決定2003年11月 1 日）

Electrospray Ionization of Bio-molecules

\section{Masamichi YAMASHITA}

\begin{abstract}
Institute of Space and Astronautical Science, Japan Aerospace Exploration Agency (JAXA) 3-1-1 Yoshinodai, Sagamihara, Kanagawa, 229-8510, Japan
\end{abstract}

(Received August 26, 2003, Accepted November 1, 2003)

\section{1. 生体分子の質量測定}

いまやステーキは特上のごちそうとみられてはいない し，ファミリーレストランでは肉の砕片を型に入れて規 格の形状にしあげたステーキを供することもあるのだ が，ステーキ肉をつくっている分子の質量を知るにはど うしたらよいだろうか。

1923年にノーベル物理学賞を受賞した R. A. Millikan は, 微細な油滴を大気中で带電させて, 沈降運動の速度 が電場中で変化するのを観察した ${ }^{1)}$ 。沈降運動は, 空気 の粘性と油滴の大きさに支配される粘性抵抗, 油滴の質 量 (半径と密度) に作用する重力によって決まる. そし て，油滴にのった電荷が印加した電場から受ける力によ り沈降運動の速度は変化する．この実験により, 電荷が 離散的な值をとることが明らかにされ，電子の電荷を測 定することができた. Millikan が実験で使った油滴の半 径はおよそ $3 \mu \mathrm{m}$ であって, 油の密度も既知であった。 私たちは Millikanにより定められた素電荷量をもと に, 油滴ならぬステーキ肉分子の質量を逆に求めること ができるだろう。どのようにステーキ肉からステーキ肉 分子を生成するかは後で検討することにして, Millikan の実験装置をそのまま転用するなら，分子量が $10^{13}$ ほど の分子の質量を測定できる，もうすこし工夫して，イオ ントラップのような 3 次元的な交流電場に上下方向の直

* 宇宙航空研究開発機構・宇宙科学研究本部 (厂229-8510 相模原市由 野台 3-1-1)
流電場を重畳させて，帯電した小さな凝縮核（氷晶）を 空間に保持し，その成長を観察するといった実験もかつ てなされている.

油滴実験相当の分子では大きすぎるというのなら，半 径が $\mathrm{nm}$ クラスの大きさの分子を考えよう．これなら， 密度として $10^{3} \mathrm{~kg} \mathrm{~m}^{-3}$ を仮定すると，分子量は $10^{4}$ にな り，一般的なタンパク分子のたぐいとなる.ではこのよ うなスケールの粒子の, 地球表面での重力・常温常圧の 空気中での運動はどのようなものだろうか：ここで登場 するのがブラウン運動である.ブラウン運動は, 1827年 に R. Brown が報告したもので，水面に浮かぶ花粉を顕 微鏡下で観察すると, 花粉から微粒子がとびでて, ジグ ザグに動くという現象である．このランダムな運動の理 論的な解析は, A. Einsteinにより1905年に発表されて おり ${ }^{2)}$, 分子拡散現象とみることができる. ブラウン運 動は，熱的な運動をしている媒質分子が粒子に衝突して 粒子へ与えられる運動量により駆動される。したがっ て，媒質分子と着目する粒子の質量比が 1 に近づくと， 粒子がランダムに運動する度合いは高まる。重力による 沈降運動とブラウン運動の効果は，およそ10 $\mathrm{nm}$ の半径 の粒子（分子量 $10^{7}$ 相当）において均衡してしまう。す なわち空気中での沈降運動から重量を正確にはかること は, 熱的な雑音により不可能になる.

そこで，分子ほどに小さな質量を精度よく測定するに は, 周囲の気体分子の熱的な運動による擾乱のない真空 中で測定することになる．分子をイオンとしたうえ，電 場や磁場により，その電荷に力を加える.イオンの運動 
の加速度は, 力を質量で除したものとなる. イオンの軌 跡や飛行時間から，イオンの質量/電荷比を測定でき， 既知の素電荷をもとに分子の質量を求めることができ る. あるいは, 既知の質量の分子での測定と比較して分 子量を求めるのが，一般的な方法である.

\section{2. 生体分子のイオン化}

質量分析の第一歩は, 試料から分子を生成し，それを イオン化することにある。まず第一段目のステーキ肉か らステーキ肉分子を作る方法を考えてみ上う。肉は，分 子と分子がから反山い，分子間の相互作用によって引き めってその形を作っている，物質を熱すると，温度が上 昇し，分子の熱運動は盛んになる．分子は分子同士が引 きあうのを脱し, 分子はばらばらにほどけて蒸発する。 それでは，ステーキ肉を加熱したらどうだろうか，ス テーキ肉分子が蒸発することはなく, 柔らかな肉は堅く 変性する.さらに加熱を続けると, 炭素分が多くなるの を反映して褐色に焦げて, 最後はいくらかの脂質と水な どの蒸気と炭状の固形物質になってしまい, ステーキ肉 分子を得るという目的を達成することはできない。

生命が水の中で始まったことにも由来して, 生物体を 構成したり，あるいは代謝される分子やそれを構成する 小さな分子は，水によく溶ける，私たちの体をみると， 摂食した食物は消化器のなかで物理・化学的な仕組み, さらには微生物の働きにより小さく分解される，分解さ れた分子は，消化管の壁の細胞によりとりこまれ，血管 中を循環する血液中に溶けて体中の細胞へと運ばれる. 植物にしても, 光合成産物やさまざまな情報をコードし た化学種は, 細胞を越え, また道管・師管といった循環 路をと抢り，植物体の内部を水溶化した状態で輸送さ れ, 植物体が構築され, 生命活動がいとなまれる.

ある分子が別の分子の液相によく溶けるかどうかを決 めるのは, Like to Like Rule とよばれる. 分子の性質が 似ていたり，それぞれの分子間の相互作用が似ているか が，溶けあう条件になる. 水とよく溶けあう分子は，い ろいるな性質が水分子に似ている，岕るいは，その分子 の周囲に水分子が強く結びつくことにより，その外側の 水分子からすれば，その分子そのものではなく結びつい た水分子を見ることになるのでよく溶けあう.

溶けあうために似るべき分子の性質のひとつは，分子 の双極子モーメントである. 水分子との親和性が高い生 体分子は総じて極性が強い分子が多い，分子と分子の間 の相互作用のありさまと，その相互作用を生みだす起源 には, いくつかの類型がある. 極性分子同士の相互作用 には強いものがあるので，加熱して分子の熱的な運動を 盛んにすることによって, 相互作用している他の分子か
らふりほどき，分子を蒸発させることは困難である．高 温条件下で蒸発する以外に化学的な反応の経路がある分 子では，蒸発する前に変性したり焦げてしまう．

液体クロマトグラフと質量分析計を組み合わせて生体 化合物の分離上分析・同定が盛んに行われるようになる 前は，化合物の極性基を化学的に修飾して分子の性質を 変えることにより，気化して分析することもあった，い ったん分子を気化することができれば，ガスクロマトグ ラフと質量分析計の組み合わせは強力な分析の手段であ った．生体分子を選択的に高感度で質量分析する方法が 求められ, 生体分子に適応したイオン化法がいくつか登 場したのである.

極性分子は, 水溶液中で水素イオンを付加したりある いは失うことにより分子イオンとして溶存したり，ある いは他のイオンとの親和性が高い傾向にある。このよう な極性の強い生体分子の性質を利用して，その分子が溶 存している液体試料から直接分子イオンを生成しようと いうのが，エレクトロスプレー法である.エレクトロス プレーにより分子イオンを生成するのは，大気圧下でな されるのだが，その理由は後で説明しょう．分子イオン の質量分析は真空下でおこなうので，ここに一工夫が必 要になる.

\section{3. ポスト・ゲノム研究に寄与するエレクト ロスプレー}

John B. Fenn 博士は巨大タンパク分子の多電荷イオ ンをエレクトロスプレー法により生成し質量分析する方 法を作り上げたことで2002年ノーベル化学賞を受賞し た.エレクトロスプレーは溶液中の生体分子を選択的に 効率よく，しかもソフトに壊さず分子イオンとして試料 液中から取り出せる．これに加えて, 多電荷イオンを生 成し質量/電荷比を小さな值とすることで, 分析系の質

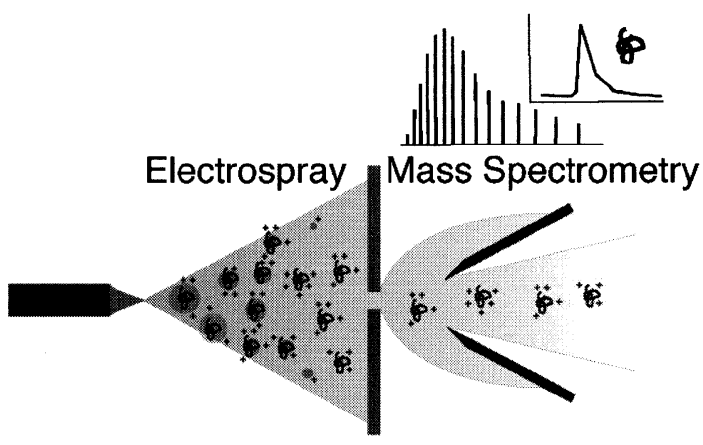

図 1 Berea College に揭げられる Fenn 博士ノーベ ル賞受賞記念額の中に示されるエレクトロス プレーの概念図. 
量走査範囲を格段に拡大でき，分子量10万におよぶタン パク分子も分析可能であるという特徵をもっている.

分子生物学の急速な進歩によって, 遺伝子の配列の多 くが解読されている，それを基礎とするポスト・ゲノム 時代の研究の焦点は, 遺伝子のコードするタンパク分子 とその生物学的な機能の解明に移っている. ところで, 近代化学の確立のひとつの基礎は, 化学反応にともなう 質量の変化と総質量の保存を明らかにしたところにあ る. 着目するタンパク分子の質量を測定し決定すること は, ポスト・ゲノム研究の基盤となる. 巨大な生体分子 の立体的な構造を, 核磁気共鳴法により解明し, 分子の 生体機能の理解を進める研究とともに, 巨大生体分子の ソフトイオン化による分子量の測定に2002年ノーベル化 学賞が与えられた. これは, 分子生物学の知識が集積さ れ，それが有効な手段となり，生物学や医学が際だって ホットな研究分野として急激な展開と発展をみせている ことへの質量分析の貢献が認められたことによる.

\section{4. エレクトロスプレー法の開発の歴史}

エレクトロスプレー質量分析の初出論文が掲載された のは1984年 9 月に発行されたJ. Phys. Chem. 誌であ る.この号は, 当時Y ale 大学に在職していたFennの 65歳を祝う特集として編集された. Fennもその発展に 奇与した分子線化学によりノーベル化学賞を1986年に受 賞する Herschbach 教授らが心温まる序文3)をこの号に 寄せている. 同誌の発行された1984年までの Fennの発 表論文リストが巻頭にまとめられ，そのリストに続いて 綴られたのが Yamashita \& Fennのエレクトロスプレー 論文 ${ }^{4)}$ であった.この論文はFenn 特集号の冒頭に揭載 され，かつ先の論文リストの掉尾を飾った．その題名 は, 'Electrospray Ion Source. Another Variation on the Free-Jet Theme’とされ，普通であれば引退の65歳をす ぎて，それまでの専門であった分子線・流体反応化学か ら生体分子の質量分析という新しい研究分野に転進する ことを高らかにうたっている. そして, 超音速自由噴流 や気体反応について築きあげてきた Fennの学問の基礎 の上に, 85歳にしてノーベル賞受賞という輝かしい評価 を得たエレクトロスプレーによる巨大生体分子の質量分 析という成果を花咲かせた。

生体分子の質量を測定するのに, 試料分子を分解する ことなくソフトに分子イオンとし， また高効率に多くの 電荷をもつ分子イオンを生成する技術を開発するには, その過程で乗り越えるべきいくつかの要石があった.

ところで, エレクトロスプレー現象そのものは扰そ 一世紀前にもすでに知られ, Yale大学のJ. Zelenyは 1914年にこの現象を記載している5). エレクトロスプ
レーは，さまざまに活用されており，自動車の塗装方法 として採用され，また宇宙で小さな推力を発生させるス ラスターでの推進剂の供給に利用できるか検討する研究 もなされている，一風かわった使われ方には，化粧品の 皮膚への塗布もなされ，その器具を質量分析に応用して いる例6)もある。

さて，エレクトロスプレー現象の応用の一つとして, M. Dole はポリスチレン・ポリマーの質量測定法を考案 して1968年に報告している7). ポリマーの（電子付加） イオンをエレクトロスプレーで生成し，そのイオンを共 存する気体の流れにのせて超音速自由噴流として真空中 に導入した：ポリマーイオンは気体分子により加速され て大きな運動エネルギーを得る．その運動エネルギーを 阻止電圧法で測定し，ポリマー分子の質量を推定する巧 みな方法である. 巨大分子のエレクトロスプレーという ことでは Dole が創始者である.しかし，その後にエレ クトロスプレー・マクロイオンについての研究は継続さ れなかった. Dole らの採用したイオン化過程や真空中 へのイオンの導入で, 実際にどんな現象が起こり，した がってマクロ分子イオンの実用的な分析法としてエレク トロスプレーを確立するにはどのような点が改善されな ければならなかったのかは，エレクトロスプレー・イオ ン化過程や真空中への導入で生起する現象の Fenn らに よる解明をなって初めて明らかになった。

Fennがエレクトロスプレーに興味を持ったのは, Fenn らが創始したシード分子線の手法を Dole が採用し たことにあった．気体のつまった部屋の壁に小さな孔を あけ，気体分子を真空中に導くとしよう。孔の径が気体 分子の自由行程（他の分子と衝突してから次に衝突する までに運動する距離）よりも小さければ，運動する気体 分子でたまたまその小さな孔の部分にむかった分子が真 空の部屋側に漏れ出る. 孔の径を大きくしていくと, 孔 （ノズル）に向かって気体が流れこみ，ノズルの一番狭 いスロート部で音速となり，その下流で超音速にまで加 速される自由噴流が形成される.

熱的な平衡状態にある気体分子の並進運動のエネル ギーの分布と平均值は, 分子量によらず温度のみできま る. 分子の平均の並進速度は同じ温度では分子量の $-1 /$ 2乗に比例するので，小さくて軽い分子の熱的な並進運 動の速度は早い. 少量の重い分子を軽い分子の気体に混 ぜた気体を真空中に超音速自由噴流で導入すると，膨張 しながら加速される気体の流れの速度は主成分である軽 い分子により支配される. 重い分子は軽い分子の流れの なかで加速される．加速された重い分子の分子線は，大 きな質量のおかげで大きな並進エネルギーを獲得する. これをシード・ビーム法と呼び, Dole の阻止電圧法に 
よるマクロイオンの質量測定に応用された．Dole と Fennは, エレクトロスプレー質量分析が高い評価を得 たあとにアメリカの質量分析学会の会場で初めて対面し たが，2 人のあたたかいふれおいの様子はエレクトロス プレー質量分析の成書 ${ }^{8}$ に寄せた Fenn による序文に詳 しい.

\section{5. 多電荷分子イオンのエレクトロスプレー による生成}

さて, エレクトロスプレーでは, 気化しにくい生体分 子の溶液を溶存状態のままイオン化する，注射針に試料 溶液を送りつつ高電圧を印加し，その電圧を上昇させて いくと, 注射針先端の電界により帯電した液体が引き出 され，初めはぼたぼたと先端から落下していた液滴の大 きさが小さくなる．射出される液滴は対向する電極板に むけて運動し, 電圧の上昇により射出される周期は短く なっていく、さらに印加電圧を増大すると，注射針の先 に円錐状の液柱が形成される. 円錐の尖った先端にはそ こでの曲率半径に反比例する急峻な電場勾配がつくられ る. 強い電界は, 帯電した円錐先端に伸びる細い液柱を ちぎり，プラス(負の高電圧を印加するときはマイナス) の多くのイオンを表面にのせた微細な帯電液滴が円錐状 液柱の先端から噴霧される.

このような強い電界中で带電液滴を生成して噴霧する というプロセスにより，イオン（プラスイオンを生成す る場合には一般的に水素イオン）を噴霧液滴の表面に高 密度に分布させることができる. 試料分子が液滴中に含 まれれば，液滴から溶媒分子が蒸発していく過程で，そ の分子と液滴表面に分布する多数のイオンが会合し, 最 後に多電荷分子イオンが生成される，微細な液滴の表面 に高密度で分布する電荷により, 液滴表面の小さな曲率 も寄与して急峻な電場が形成され, 分子イオンが液滴か ら電場の作用によって離脱する機構も提唱されている.

電界により試料溶液を噴霧することで多くの電荷をも つ分子イオンを容易に生成できるエレクトロスプレーの 特質は, 類似のイオン化法, たとえば注射針周囲の強い 気流により液体試料を噴霧してイオン化するといった方 法に対するエレクトロスプレーの優位性を際だたせてい る. 液体試料を流体力学的な方法で噴霧しても, 液滴に ふくまれる正負のイオンの数はいずれかにかたより電気 的中性は保たれない，したがって，分子イオンを生成す ることは可能であるのだが，多電荷分子イオンを生成す ることはできない，分子量が10万にもおよぶ巨大な生体 分子を多電荷分子イオンにすることで，エレクトロスプ レー法は普通の質量分析計でこれらの巨大分子を分析す るのを可能にした.
注射針に高電圧を印加して, 円錐状の液柱を形成し， その先端に強い電界を生成するのがエレクトロスプレー のみそである、ところが， 円錐状の液柱を形成するには 条件がある、溶媒分子の双極子モーメントなどの特性, 液体の組成によりきをる粘性などいくつかの物性, イオ ンの濃度などに依存して, エレクトロスプレー法を適用 できるかが決まる。常に新鮮な試料溶液によって鋭い液 柱の先端がつくられ，末た極性の強い生体分子を選択的 にイオン化できる. 長所は短所となり, 試料溶液の組成 や試料分子のタイプによってはイオン化することができ ないという弱点をエレクトロスプレー法はもっている.

\section{6. エレクトロスプレーによる分子イオンの 生成過程}

大気圧下でエレクトロスプレーにより液滴を噴霧する と, 微細で表面積が大きいために蒸発が盛んにおこる. 帯電液滴から溶媒分子が蒸発すると, 液滴表面のイオン 同士の反発が表面張力を上回るようになる，液滴を球状 の形態にまとめている表面張力がイオンの反発により打 ち消されると, 周囲からの摂動により表面波が励起さ れ, 液滴はいくつかの小滴に分裂する。液滴の分裂は体 積に比べて表面積を大きくし, さらに蒸発は加速され る. 周囲気体の熱浴効果は, 蒸発の潜熱により冷却され る液滴にエネルギーを供給して, 迅速な蒸発を継続させ 万.

熱浴気体の効果は, 蒸発の促進ばかりではない.イオ ンや電子が電界で加速され高いエネルギーを得て, たと えば分子イオンに衝突してそれを分解してしまうような 反応を熱浴気体は抑止する。すなわち, 熱浴分子との頻 繁な衝突により, 電界中で加速される荷電粒子のエネル ギーを常温での熱エネルギーのレベル以上には上げない 効果がある．負イオンを生成するエレクトロスプレー9) では, とがった先端から電子が容易に放出される. 熱浴 気体に電子親和性の強い分子を加えることにより, 電子 などが電界中で加速されて引き起こす放電反応を抑制す る.このように, エレクトロスプレーによるイオン化 は, 正負いずれの分子イオンであっても，およそ試料溶 液中に溶存していたときとかわらない状態で分子イオン を得ることができ, 試料分子を分解しないソフトなイオ ン化法と特徵づけられる.

Fenn らは, 通常の質量分析計で測定可能な範囲の分 子量をもつ生体分子を試料としてまず用い, 測定された 質量スペクトルからエレクトロスプレー・イオン化にど のような現象が関与しているのかを明らかにした.エレ クトロスプレーによれば，分子を分解してフラグメン ト・イオンを生じたりすることなく, もとの分子の質量 
をそのままに残すインタクトな分子イオンを与えること を実証したエエレクトロスプレーの動作条件によって は, 溶媒和した分子イオンが得られるのを示し, エレク トロスプレーを実用的なイオン化源とするための指針を 与えた.

\section{7. 流体力学の質量分析への貢献}

分子イオンの精度の高い質量の測定は, 熱的な運動を している周囲の気体分子との衝突による妨害を避けるた め真空中でなされる，そこで，大気圧下でエレクトロス プレーにより生成した分子イオンの質量を分析するため には, 分子イオンを真空中へ導入しなければならない.

このときに，熱浴気体も分子イオンと同時に真空中に膨 張しながら噴出する.エレクトロスプレーを実用的なイ オン源へと発展させるには，この真空中への自由噴流に ついての深い理解が求められた.

Fennのすぐれた業績と科学への貢献は, 流体力学と 化学をつなぎ分子線化学をはじめたところにある。

Fenn は1940年にYale 大学で溶液化学の研究により学位 を取得した後, ラム・ジェット・エンジンの開発にたず さわり, 流体力学と化学の境界領域を研究分野とした. 米海軍研究所のロンドン駐在勤務中（1955-56年）にド イツの分子線研究に触れ, 超音速自由噴流を活用した分 子線化学の創始者の一人となった. とりわけ, 重い分子 を混ぜて高エネルギーの分子線を生成するシード・ビー ム法はFennの得意技であった．Doleによるマクロイオ ンの質量分析もそうだが，シード・ビーム技術に関連す る応用の一つは, ガスクロマトグラフと質量分析計をつ なぐインターフェースとして用いられるジェット・セパ レータである.ヘリウムなどの軽いキャリアガスの中に 含まれる重い試料分子を濃縮して質量分析計に導入する ために，超音速自由噴流の特性を応用し，噴流の中心部 での重い分子の割合が分子の熱的な並進速度の質量依存 性もあって増大するという流体力学的な効果が,このイ ンターフェースに活用されている.

エレクトロスプレーでの Fenn らの貢献は, 真空中に ノズルから噴出する超音速自由噴流中で気体が断熱膨張 し急激に温度がさがり分子の凝縮が進行することへの鋭 い洞察のもとに，そのような凝縮を防止する手だてを工 夫したことにもある。噴流中の温度は膨張する前の試料 ガスの絶対温度の1/100ほどにも急激に降下する．凝縮 性の分子が膨張する噴流気体中に存在するなら, 凝縮の 過飽和度の高い領域が形成されて容易に凝縮が進む. 膨 張の過程で温度ばかりでなく気体分子の密度もまた急激 に低下する，自由噴流の下流では，分子と分子の衝突も 起こらなくなり，自由噴流中で反応した生成物は凍結さ
れて保存される. 自由噴流中では, このように温度と密 度が急激に低下するので, 凝縮現象を初めとする気体反 応の素過程を研究する反応の場として活用されてきた。

Fenn らは, 気体分子の㠜縮の素過程を超音速自由噴流

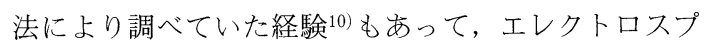
レー技術を実用化する要点に, このような凝縮過程が自 由噴流中で容易にすすむこと，またそれを制御する必要 のあることを的確に探り当てることができた.

さて, 分子イオンと極性を持つ分子との間の相互作用 は, 異なる符号の電荷を有する二つの粒子間に働くクー ロン力による相互作用に次いで強く, またその作用は遠 くまで達する、これにもとづいて, 分子イオンと極性分 子の会合反応の断面積は大きい. C. T. R. Wilson は, 霧箱による宇宙線の研究で1927年のノーベル物理学賞を 受賞している. 過飽和のアルコールなどの蒸気をいれた 箱の中に宇宙線が入射すると, その飛跡にそって気体分 子が電離し, 生成したイオンが凝縮核となって蒸気が凝 縮し，宇宙線の飛跡を可視化することができる.

生体分子を溶解する溶媒は, 極性の高い分子の多いこ とは, Like to Like Ruleで説明できる. エレクトロスプ レー・イオン源の大気圧のスプレー領域でせっかく溶媒 分子が蒸発して裸の生体分子イオンを生成できても, 真 空中に膨張する自由噴流に溶媒分子が含まれると, 瞬く 間に分子イオンは溶媒和して雪たるるとなり，もとの姿 にもどってしまう，雪だるまとなった分子イオンを質量 分析しても, 分子の質量は求めることはできない.

この問題に対する流体力学的な解決は, 電界により帯 電液滴のノズルに向かう運動方向と対向して, 乾燥した 熱浴気体を流すことであった。除湿器からでる乾燥空気 を洗濯物にあて水分を風で吹き飛ばすという，日常にお こなう工夫に通じるところがある。带電液滴を真空中へ の試料導入部方向へと電界により誘導しながら, 蒸発し た電荷をもたない溶媒分子を対向する気流で押し流して イオン源から除去する．この工夫により，自由噴流中で 雪だるまとなるのをふせぎ，分子イオンのみを真空中に 導入して質量分析することが可能になった.

エレクトロスプレーの開発は, 後からみれば誰でも思 いつく発想を, 理詰めで積み上げてその有用性を実証し たのである、その発想が単純なだけに, 応用範囲は広い ものになった. さらに, Fennの流体力学などの学問的 背景は, エレクトロスプレーを液体クロマトグラフとい った分析器と質量分析計のインターフェースとして確立 するのに，キャピラリ・ノズルを用いて電界に逆らって 分子イオンを流体力学的に輸送し真空中に導く技術の発 明につながった：このようにして，多くの電荷をもつイ オンによる巨大な生体分子のエレクトロスプレー質量分 
析法 ${ }^{11)}$ が, Fennのもとで確立されたのである.

肌の色，国籍，宗派，政治信条を問わず，実力あるも のをグループに加え研究機会を与えその能力を存分に発 揮させるという, アメリカの「強さ」を一人の科学者の なかに具現する暖かな Fenn 博士の人柄は, リベラルな 校風で知られるYale 大学に在籍していたことにもよろ うが, ケンタッキー州のアパラチア山中にある Berea College に学んだことによるところが大きい. その歴史 は南北戦争 (1861-1865) 直前にさかのぼり, 奴隷解放 運動の一環として開学された. ケンタッキー州は南部に 属したものの, 北部諸州での工業化を進めた鉄鋼業のた めの採炭地として「解放」奴隷や, 東欧から移民してき た労㗢者を吸収していた. Berea College は, 貧しい家 庭の多いアパラチア山地の向学心に富む優れた子女を対 象に，学費を徵収することなく，性や肌の色に関わりな く学ばせてきている. 1866年の学生数187のうち過半を 占める97人は黒人でめった. 被差別階層や人種への教育 投資を無駄なものとして抑制する動きに真っ向から反対 する教育の理念と実践が，Berea Collegeの百年を越す 歴史に刻まれている. Fenn 博士のノ一ベル化学賞受賞 を後世につたえる記念額は，このBerea College に揭げ られる。

\section{〔文献〕}

1) R. A. Millikan: On the elementary electrical charge and the Avogadro constant, Phys. Rev., 2 (1913) 109143.
2) A. Einstein: Über die von der molekularkinetischen Theorie der Wärme geforderte Bewegung von in ruhenden Flüssigkeiten suspendierten Teilchen, Annalen der Physik, 4 Folge, 17 (1905) 549-560.

3) C. E. Kolb and D. R. Herschbach: John Bennett Fenn, J. Phys. Chem., 88 (1984) 4447-4448.

4) M. Yamashita and J. B. Fenn: Electrospray Ion Source. Another Variation on the Free-Jet Theme, J. Phys. Chem., 88 (1984) 4451-4459.

5) J. Zeleny: The Electrical Discharge from Liquid Points, and a Hydrostatic Method of Measuring the Electric Intensity at their Surfaces, Phys. Rev., (2 ${ }^{\text {nd }}$ Series), 10 (1914) 69-91.

6) R. Arakawa, S. Uemura, T. Ichihara and I. Katakuse: A handy ionized spray source using a cosmetic ionizer for ESI mass spectrometry, J. Mass Spectrom. Soc. Jpn., 51 (2003) 477-480.

7) M. Dole, L. L. Mack and R. L. Hines: Molecular Beams of Macroions, J. Chem. Phys., 49 (1968) 22402249.

8) R. B. Cole: Electrospray Ionization Mass Spectrometry, (John Wiley \& Sons, New York, 1997).

9) M. Yamashita and J. B. Fenn: Negative Ion Production with the Electrospray Ion Source, J. Phys. Chem., 88 (1984) 4671-4675.

10) M. Yamashita, T. Sano, S. Kotake and J. B. Fenn: Dimer Depletion by Solute Species in Free Jet Expansion, J. Chem. Phys., 75 (1981) 5355-5361.

11) J. B. Fenn, M. Mann, C.-K. Meng, S.-F. Wong and C. M. Whitehouse: Electrospray Ionization for MassSpectrometry of Large Biomolecules. Science, 246 (1989) 64-71. 